\title{
ANTIOXIDANT ACTIVITY AND SECONDARY METABOLITES IN SELECTED VEGETABLES IRRIGATED WITH SEWAGE WATER
}

\author{
ZAFAR, S. $^{1 *}-$ ASHRAF, M. Y. ${ }^{2}-$ ALI, Q. $^{1}-$ ASHRAF, A. ${ }^{3}-$ ANWAR, $S .{ }^{1}-$ IQBAL, N. ${ }^{1}$ \\ - KAUSAR, A. ${ }^{1}$ - NOUMAN, A. ${ }^{1}-$ ALI, M. ${ }^{1}$ - ZAFAR, M. A. ${ }^{1}-$ FEROZ, K. ${ }^{1}$ \\ ${ }^{1}$ Department of Botany, GC University, Faisalabad, Pakistan \\ (Dr. Qasim Ali: +92-0321-6692927, e-mail: qasimbot_uaf@yahoo.com;Dr. Sumera Anwar: \\ +92-0334-6518990, e-mail: anwer_sumera@yahoo.com; Dr.Naeem Iqbal: +92-0300-7979767, \\ email:drnaeem@gcuf.edu.pk; Dr.Abida Kausar:+92-0322-6393121,e-mail: \\ kausaragc@yahoo.com; Mohsan Ali: +92-0306-7200721,e-mail: \\ mohsinrashid242@gmail.com; Ali Nouman: +92-0300-6694992, e-mail: \\ alinoman@gcuf.edu.pk; Muhammad Amir Zafar: +92 -0335-1867207, e-mail: \\ amir.zafar55@yahoo.com; Komal Feroz:e-mail: komalferoz@ymail.com) \\ ${ }^{2}$ Nuclear Institute of Agriculture and Biology, NIAB, Faisalabad, Pakistan \\ (phone: +92-0300-7623885; e-mail: niabmyashraf@gmail.com) \\ ${ }^{3}$ Department of Zoology, GC University, Faisalabad, Pakistan \\ (phone: +92-0322-6278383; e-mail: asmabinm@gmail.com) \\ *Corresponding author \\ e-mail: saraomer_gcuf@yahoo.com \\ (phone: +92-9201488, +92-0321-7831003) \\ (Received $15^{\text {th }}$ Apr 2016; accepted 30 $0^{\text {th }}$ Jul 2016)
}

\begin{abstract}
The study was conducted to investigate the impact of various concentration of domestic waste water on growth, physiological, and biochemical characteristics of tomato, okra and pumpkin. Sewage water was applied of $50 \%$ and $100 \%$ on vegetables grown under field conditions. Irrigation with tubewell water was considered as control. At maturity data for growth attributes was recorded. Maximum fresh weight of root, shoot and fruit was in tomato at 50\% sewage water treatment followed by control. Dry weight also exhibited a considerable increase at 50\% sewage water application. However, a decline in chlorophyll a, b and carotenoid contents was observed at 100\% sewage water. Antioxidants and secondary metabolites increased and their maximum values were recorded at $100 \%$ sewage treatment in all the three vegetables.
\end{abstract}

Keywords: domestic effluents, contamination, flavonoid, growth, MDA

\section{Introduction}

Shortage of fresh water resources is a serious issue, due to which resource poor countries are using marginal quality water for irrigation purposes. Waste water may contain some nutrients useful for agriculture, however, its continuous application increases toxic metals in plants and soil (Rattan et al., 2005). Sewage water also contains industrial wastes and toxic metals, polluting soil and food chain (Khan et al., 2008). In Pakistan inadequacy of irrigation water comes up with the integrative use of ground water and industrial and sewage effluents for agriculture (Khan et al., 2013). Major cities of Pakistan produce sewage 116,590 million gallons/day irrigating 32,000 ha of land (FAO, 2002; Musa et al., 2013).

Tomato (Solanum lycopersicum L.), okra (Abelmoschus esculentus (L.) Moench) and pumpkin (Cucurbita pepo L.) are a vital part of human diet, because they are important 
source of nutrients like proteins, fiber, vitamins, iron and calcium (Ullah et al., 2009). Waste-water irrigation results in elevated metal uptake by most of the vegetables grown particularly in peri-urban areas thus metals become a vital part of food chain (Farooq et al., 2008). Waste water irrigation may cause growth stage dependent sensitivity in vegetables (Baksh, 2005). It has been estimated that approximately 1/10th of the global population is considered to eat food from plants irrigated with wastewater (Kouser and Samie, 2009).

Consequently, it is imperative to look deep into the prospects of sewage water irrigation for managing this nutrient rich resource. On the other hand, unveiling specific relationship between fertigation with waste-water and a crop is also important for appropriate application (Kumar et al., 2010). Therefore, the present study was executed to evaluate the role of waste-water fertigation for vegetable growth, development and sustainable production. Additionally, incorporation of the present knowledge into fertigation systems will likely to be a promising strategy for optimizing crop productivity in irrigation scarce areas.

\section{Materials and methods}

A field experiment was performed in Pakpattan district, Punjab, Pakistan to evaluate the effect of domestic effluents on morpho-physiological and biochemical attributes in tomato (Solanum lycopersicum L.), okra (Abelmoschus esculentus (L.) Moench) and pumpkin (Cucurbita pepo L.).

\section{Field preparation}

The field was prepared by dividing the main plot into three sub plots of $3 \times 3 \mathrm{~m}^{2}$ and digging the soil upto 1 foot. The three sub plots were separated by polythene sheet, filled with clay and sand in 1:1 ratio. The experimental design was split plot. The treatments applied were: control (tube well water), 50\% (sewage water blended with tube well water) and $100 \%$ sewage water.

Seeds were collected from AARI (Ayub Agricultural Research Institute) Faisalabad, Pakistan and sown in the appropriate growing season.

\section{Water analysis}

Physico-chemical analysis of waste water (Table 1) indicated that the EC values recorded were higher than the suitable limit for most of the crops (EPA, 1991). The $\mathrm{pH}$ was slightly alkaline (United State Salinity Laboratory staff, 1954). Analysis of waste water indicated the presence of toxic metals were more than the permissible limits. Cadmium was much higher than the recommended value. Similarly $\mathrm{Cu}, \mathrm{Pb}$, and $\mathrm{Zn}$ were in higher concentrations.

Table 1. Physico-chemical characteristics of waste-water used for irrigation

\begin{tabular}{cccc}
\hline Parameters & Unit & Waste water & Recommended values \\
\hline $\mathrm{pH}$ & & 7.3 & $6.0-8.5$ \\
$\mathrm{EC}$ & $\mathrm{mScm}^{-1}$ & 3.73 & 3 \\
Carbonate & $\mathrm{meqL}^{-1}$ & 2.4 & \\
Bicarbonate & $\mathrm{meqL}^{-1}$ & 5.1 & \\
Heavy metals/ Ions & $\mathrm{mgkg}^{-1}$ & - & \\
\hline
\end{tabular}




\begin{tabular}{cccc}
\hline $\mathrm{Zn}$ & - & 3.145 & $\leq 2.0$ \\
$\mathrm{P}$ & - & 13.78 & $<0.01$ \\
$\mathrm{Cd}$ & - & 0.625 & \\
$\mathrm{~K}$ & - & 115 & $\leq 5.0$ \\
$\mathrm{Fe}$ & - & 0.519 & $<5.0$ \\
$\mathrm{~Pb}$ & - & 7.432 & $<0.2$ \\
$\mathrm{Cu}$ & - & 1.11 & \\
\hline
\end{tabular}

\section{Physico-chemical characteristics of the soil}

The $\mathrm{pH}$ of soil was 7.3, slightly alkaline and was in safe limit with reference to standard limit of 8.5 (Table 2). EC value of soil was $2.1 \mathrm{mS} / \mathrm{cm}$, which was in the safe limit according to the standard permissible limit (Ilaco, 1985; MAAF, 1988; CCME, 2007; WHO, 2007). In soil, heavy metals were also in the safe limit.

Table 2. Physico-chemical properties of the soil

\begin{tabular}{c|c|c|c}
\hline Parameters & Unit & Soil & Safe limits \\
\hline Texture & & Sandy loam & \\
$\mathrm{pH}$ & & 7.3 & $\leq 8.5$ \\
$\mathrm{EC}$ & $\mathrm{mScm}^{-1}$ & 1.9 & $2-4$ \\
Heavy metals/ Ions & $\mathrm{mgKg}^{-1}$ & - & \\
$\mathrm{Zn}$ & - & 3.01 & 300 \\
$\mathrm{~K}$ & - & 1400 & - \\
$\mathrm{Fe}$ & - & 2.35 & - \\
$\mathrm{P}$ & - & 40.1 & 300 \\
$\mathrm{Cd}$ & - & 0.21 & 3 \\
$\mathrm{Cu}$ & - & 17 & 140 \\
$\mathrm{P}$ & - & 41.1 & \\
\hline
\end{tabular}

\section{Fresh and dry weight}

The fresh weight and dry weight was measured in grams for shoot, root and fruit by using electrical balance. For dry weight samples were kept in an oven at $70{ }^{\circ} \mathrm{C}$ for 72 hours.

\section{Pigment analysis}

The fresh leaves $(0.5 \mathrm{~g})$ were homogenized in chilled acetone (80\%). Centrifuge (3000 rpm/10 mints) at $4{ }^{\circ} \mathrm{C}$. Separate the supernatant and measure absorbance at 663,645 and $480 \mathrm{~nm}$ respectively with spectrophotometer. Chlorophyll contents were determined by the method of Arnon (1949) and carotenoid contents were calculated as described by Kirk and Allen (1965). 


\section{Antioxidant enzymes}

Fresh leaves $(0.5 \mathrm{~g})$ of tomato, okra and pumpkin were ground in $8 \mathrm{ml}$ of $50 \mathrm{mM}$ phosphate buffer $\mathrm{pH}$ (7.8). The homogenate was centrifuged at $15000 \mathrm{x} \mathrm{g}$ for $20 \mathrm{~min}$ at $4{ }^{\circ} \mathrm{C}$. The supernatant was used for the assay of enzymes activity.

\section{Catalase (CAT)}

The activity was assayed in a $3 \mathrm{ml}$ reaction solution containing phosphate buffer (50 $\mathrm{m} M, 7.0 \mathrm{pH}), \mathrm{H}_{2} \mathrm{O}_{2}(5.9 \mathrm{~m} M)$ and $0.1 \mathrm{ml}$ of enzyme extract as described by Chance and Maehly (1955). A decline in activity of catalase enzyme due to $\mathrm{H}_{2} \mathrm{O}_{2}$ consumption was measured at $240 \mathrm{~nm}$ absorbance after every $20 \mathrm{sec}$. A one unit catalase activity defined as a change in absorbance of 0.01 unit $\mathrm{min}^{-1}$.

\section{Peroxidase (POD)}

The activity was determined as the peroxidation of $\mathrm{H}_{2} \mathrm{O}_{2}$ and guaiacol as an electron donor (Chance and Maehly, 1955). Add phosphate buffer (50 mM, pH 5), $20 \mathrm{~m} M$ of guaiacol, $\mathrm{H}_{2} \mathrm{O}_{2}(40 \mathrm{~m} M)$ and $0.1 \mathrm{~mL}$ enzyme extract in a reaction solution. Formation of tetra-guaiacol resulted in an increase in the absorbance at $470 \mathrm{~nm}$ measured after every $20 \mathrm{sec}$. One enzyme unit was the amount responsible for an increase in OD value of $0.01 / 1 \mathrm{~min}$. The activity was expressed as unit $\min ^{-1} \mathrm{~g}^{-1}$ fresh weight basis.

\section{Superoxide dismutase (SOD)}

It was determined by the method of Giannopolitis and Ries (1977) by measuring the inhibition rate of nitroblue-tetrazolium (NBT) reduction by xanthine oxidase acting as hydrogen peroxide generating agent. The absorbance was measured at $560 \mathrm{~nm}$ by using a UV-visible (IRMECO U2020) spectrophotometer. One unit activity reflected 50\% photochemical inhibition of NBT.

\section{Ascorbate peroxidase (APX)}

The activity was monitored by a decrease in ascorbic acid absorbance at $290 \mathrm{~nm}$ (extinction coefficient $2.8 \mathrm{mM} \mathrm{cm}-1$ ) in $1 \mathrm{ml}$ reaction mixture containing phosphate buffer (50 mM, pH 7.6), $0.1 \mathrm{~m} M$ Na-EDTA, $12 \mathrm{~m} M \mathrm{H}_{2} \mathrm{O}_{2}, 0.25 \mathrm{mM}$ ascorbic acid as described by Cakmak, (1994).

\section{Malondialdehyde (MDA)}

The estimation was done by using the method of Camak and Horst (1991). Ground fresh leaves $(1 \mathrm{~g})$ in $20 \mathrm{ml}$ tri-chloroacetic acid $(0.1 \%)$ and centrifuge at $12000 \mathrm{~g}$ for 10 min. Take $1 \mathrm{ml}$ of the supernatant and added $4 \mathrm{ml}$ of $20 \%$ TCA comprising $0.5 \%$ thiobarbituric acid and then it was heated for $30 \mathrm{~min}$., at $95^{\circ} \mathrm{C}$ in a water bath and then immediately cooled on ice. After centrifuge for $10 \mathrm{~min}$., at $12000 \mathrm{~g}$, the absorbance of the supernatant was read at 532 and $600 \mathrm{~nm}$. The contents of MDA were calculated using extinction coefficient of $155 /(\mathrm{mM} / \mathrm{cm})$ with the help of formula:

$$
\text { MDA level }(\mathrm{nmol})=\Delta(\text { A } 532 \mathrm{~nm}-\mathrm{A} 600 \mathrm{~nm}) / 1.56 \times 10^{5}
$$




\section{Total leaf phenolics content}

To the $5 \mathrm{ml}$ Folin-Ciocalteu reagent (formerly diluted with water 1:10 v/v) along with $4 \mathrm{ml}(75 \mathrm{~g} / \mathrm{L})$ of $\mathrm{Na}_{2} \mathrm{CO}_{3}$, added the plant extract was added. The tubes were vortexed for $15 \mathrm{sec}$ and allowed them to stay for $30 \mathrm{~min}$ at $40{ }^{\circ} \mathrm{C}$ for developing color. The absorbance read at $765 \mathrm{~nm}$ using Folin-Ciocalteu method (Wolfe et al., 2003). The absorbance was expressed as $\mathrm{mg} \mathrm{g}^{-1}$ tannic acid and the amount worked out by using the equation based on the following calibration curve:

$y=0.1216 \mathrm{x}, r^{2}=0.9365, \mathrm{x}$ was the absorbance, $\mathrm{y}$ the tannic acid equivalent $(\mathrm{mg} / \mathrm{g})$

\section{Total flavonoid contents}

The contents were determined with the help of spectrophotometer by using the method of Park et al. (2008). Total flavonoid contents were expressed as mg of rutin equivalents per gram of dried fraction.

\section{Statistical analysis}

The results were statistically analyzed by using the software program Statistix 8.1 at $\mathrm{P} \leq 0.05$. Means and standard errors were assessed on Microsoft Excel -2007 Version and the significance of means was tested at $5 \%$ probability level using Least Significant Difference test.

\section{Results}

Sewage water applied in $100 \%$ concentration reduced plant fresh weight in tomato (Solanum lycopersicum L.), okra (Abelmoschus esculentus (L.) Moench) and pumpkin (Cucurbita pepo L.) (Fig. 1). Application of 50\% concentration of sewage water resulted in an increase in fresh weight in shoot of okra and pumpkin by $36 \%$ and $16 \%$. In tomato 50 and $100 \%$ sewage reduced shoot fresh weight from control (773 g) to 630 and 352 g respectively. However, $50 \%$ domestic sewage water increased fresh weight in tomato, okra and pumpkin (Fig. 1). Irrigation with $100 \%$ sewage water decreased root fresh weight by $4 \%, 8 \%$ and $43 \%$ in pumpkin, tomato and okra, respectively. Fruit fresh weight decreased in the order as $50 \%$ sewage water $>$ control $>100 \%$ sewage water.

Polluted water significantly affected shoot dry weight of all vegetables (Table 3.). A decrease in dry weight at $100 \%$ concentration of sewage water was observed in tomato, okra and pumpkin by $30 \%, 20 \%$ and $13 \%$, respectively. At $100 \%$ sewage water dry weight of fruit was $99 \mathrm{~g}$ in tomato and $42 \mathrm{~g}$ in okra. Different concentrations of sewage water also affected root dry weight (Fig. 1). An increase of 20, 28 and 60\% in root dry weight was observed in tomato, okra and pumpkin, respectively as compared to that in control. In general tomato plants had the highest root dry weight $25 \mathrm{~g}$ at $50 \%$ sewage water and pumpkin roots had minimum $5 \mathrm{~g}$ at $100 \%$ sewage water. In okra and pumpkin, dry weight of fruit increased at 50\% concentration of sewage water over control (Fig. 1). Dry weight of fruit in tomato, okra and pumpkin decreased by 38,17 and $32 \%$ respectively at $100 \%$ sewage water application. Overall, maximum dry weight of fruit was in pumpkin $(6 \mathrm{~g})$ at $50 \%$ sewage water application.

A decline in chlorophyll contents was observed at 50 and $100 \%$ application of domestic sewage water in all the vegetables (Fig. 1). Reduction in tomato, okra and 
pumpkin at $50 \%$ sewage water was $12 \%, 30 \%$ and $32 \%$ respectively and at $100 \%$ sewage water it was $40 \%, 56 \%$ and $21 \%$ as compared to control.

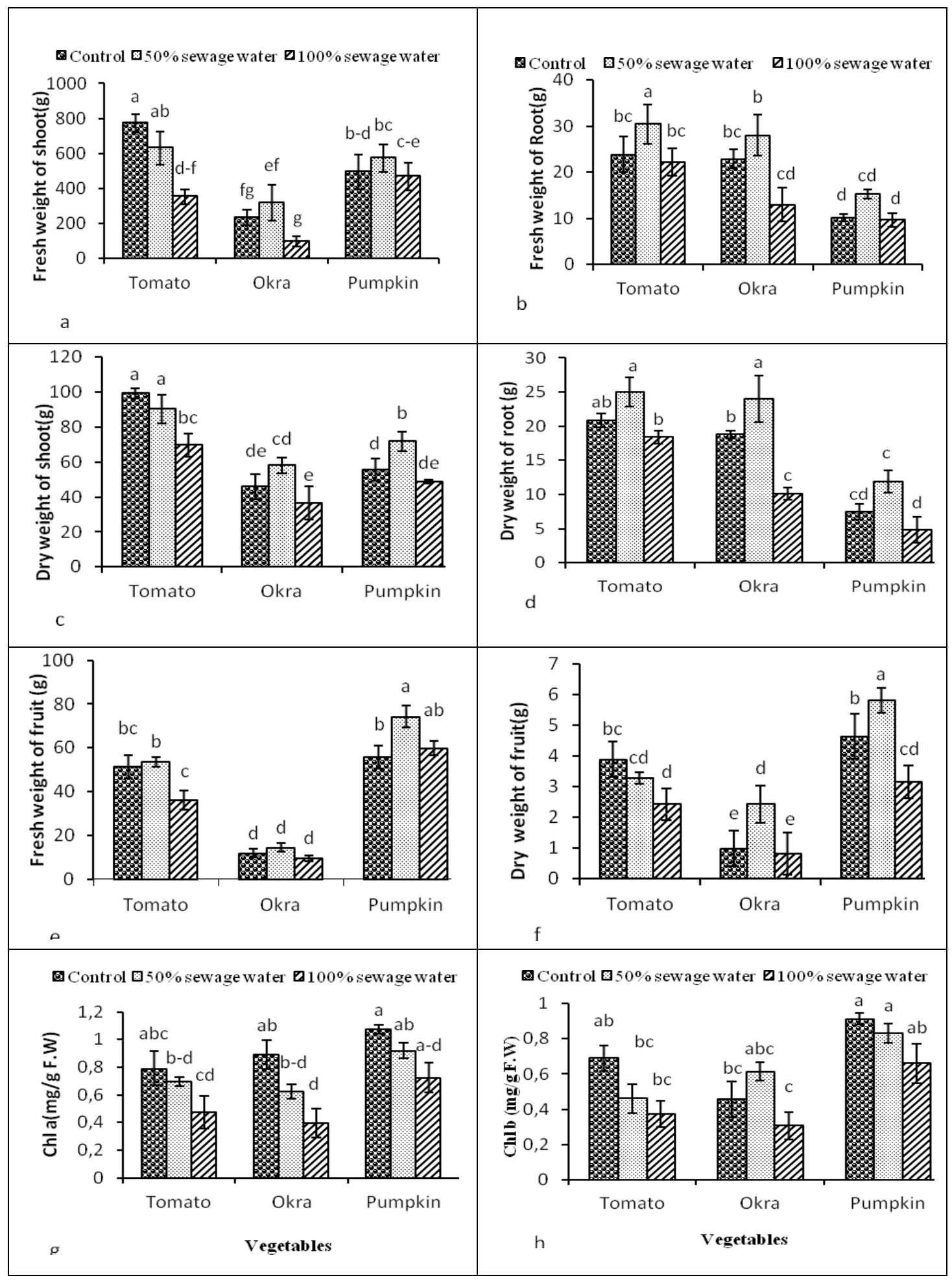

Figure1. Effect of domestic sewage water on morpho-physiological attributes of tomato, okra and pumpkin. Bars with different letters in each group show significant difference at $p<0.05$ 
Reduction in chlorophyll $b$ contents was 0.6 to 0.4 and 0.9 to $0.8 \mathrm{mg} / \mathrm{g}$ respectively at $50 \%$ waste-water treatment in tomato and pumpkin (Fig. 1). However, an increase in chlorophyll $b$ contents from 0.4 to $0.6 \mathrm{mg} / \mathrm{g}$ was observed in okra at $50 \%$ waste-water treatment. At $100 \%$ irrigation of polluted water reduction in chlorophyll $b$ was 0.6 to $0.37,0.4$ to 0.31 and 0.9 to $0.66 \mathrm{mgg}^{-1}$ respectively in tomato, okra and pumpkin. An increase in the carotenoid contents at 50 and $100 \%$ concentration of domestic sewage water was observed in all three vegetables. At $50 \%$ irrigation of polluted water, the carotenoid contents increased from 0.5 to $0.7,0.9$ to 1.1 and 1.12 to $1.2 \mathrm{mg} \mathrm{ml}^{-1}$ in tomato, okra and pumpkin, respectively.

Sewage water irrigation with 50 and $100 \%$ increased the ascorbate peroxidase activity in all three vegetables. Generally the APX activity at $100 \%$ sewage water in tomato was 3.15 ( $\mathrm{min}^{-1} \mathrm{~g}^{-1} \mathrm{~F}$. wt.) and $1.908\left(\mathrm{~min}^{-1} \mathrm{~g}^{-1} \mathrm{~F}\right.$. wt.) in okra. A significant increase in the SOD activity 247 to $276\left(\mathrm{~min}^{-1} \mathrm{~g}^{-1} \mathrm{~F}\right.$. wt.) was observed in tomato with irrigation of sewage water. At $100 \%$ sewage water the SOD activity was the highest in tomato $276\left(\mathrm{~min}^{-1} \mathrm{~g}^{-1} \mathrm{~F}\right.$. wt.) and the least in okra $176\left(\mathrm{~min}^{-1} \mathrm{~g}^{-1} \mathrm{~F}\right.$. wt.).

Peroxidase activity increased with the irrigation of different concentrations of sewage water in all the vegetables (Fig. 2). Sewage water at $50 \%$ irrigation increased the POD activity in pumpkin, tomato, okra and from 57 to 68,91 to 108 and 52 to 75 (min-1 g-1 F. wt.) respectively. The highest POD activity at 50\% irrigation with domestic sewage water was 108 (min-1 g- $1 \mathrm{~F}$. wt.) in tomato and the least was in okra 68 (min-1 g-1 F. wt.). Irrigation with 50\% domestic sewage water increased the catalase activity from 182 to 199 and 69 to $101\left(\mathrm{~min}^{-1} \mathrm{~g}^{-1} \mathrm{~F}\right.$. wt.) in tomato and pumpkin, respectively. An increase in MDA content was observed in pumpkin $43 \%$ and $49 \%$, tomato $69 \%, 117 \%$ and okra $76 \%, 111 \%$ over control under $50 \%$ and $100 \%$. The order of increase in flavonoid contents was $100 \%$ sewage water $>50 \%$ sewage water $>$ control. Irrigation of $50 \%$ and $100 \%$ sewage water increased the phenolic content in okra $27 \%, 33 \%$, tomato $56 \%, 91 \%$ and pumpkin $46 \%$ and $96 \%$ over control (Fig. 2). Overall, the highest concentration of phenolics was found in tomato followed by okra and pumpkin.

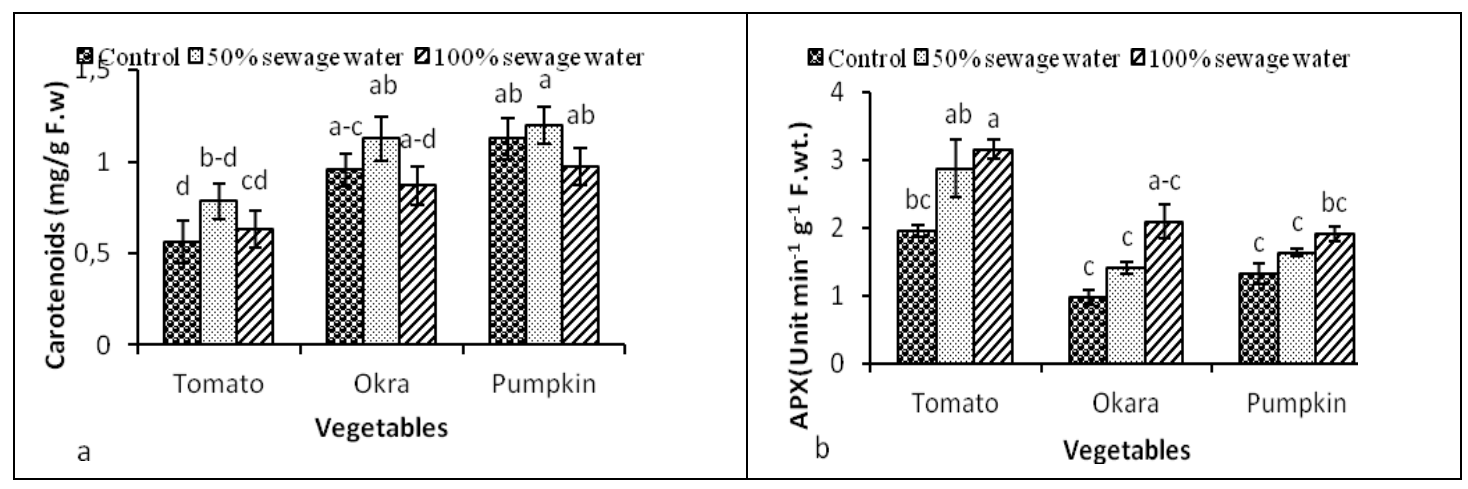




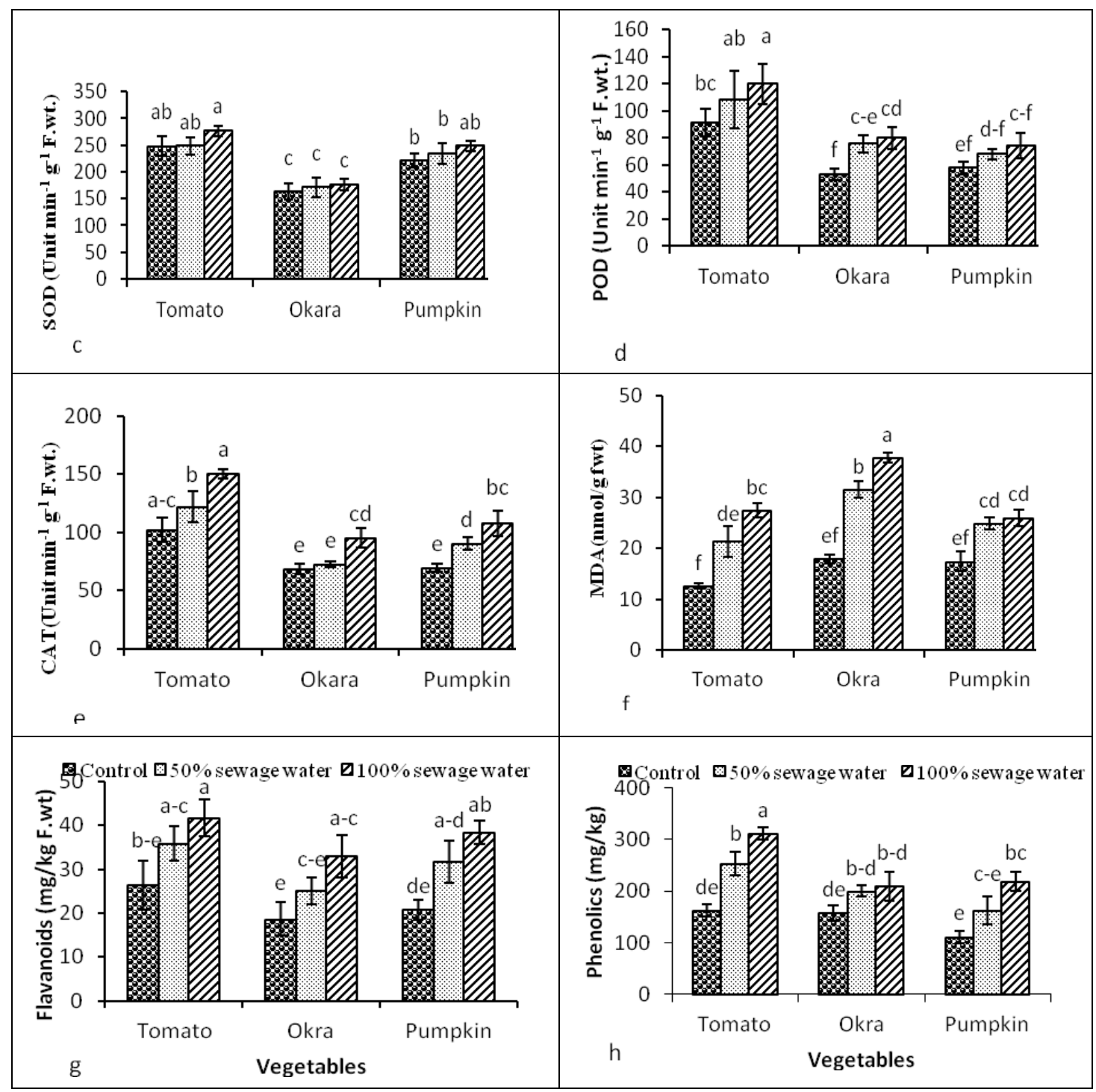

Figure 2. Effect of domestic sewage water irrigation on antioxidant activities of tomato, okra and pumpkin irrigated with sewage water. Bars with different letters in each group show significant difference at $p<0.05$.

\section{Discussion}

Application of $100 \%$ sewage water reduced the fresh and dry weights of tomato (Solanum lycopersicum L.), okra (Abelmoschus esculentus (L.) Moench) and pumpkin (Cucurbita pepo L.). Similar, decrease in biomass was observed with the application of 20 and $30 \%$ polluted water in tomato plants (Saeed and Ahmed, 2009). A decrease in fresh biomass of shoot under sewage application was also investigated in wheat (Kakar et al., 2010). Irrigating Leucaena leucocephala with polluted water reduced growth and plant height (Hassan and Ali, 2013). Toxic metals may accumulate in the foliage parts of the plant, disturbing the physiological and biochemical activities in plant that ultimately reducing the growth (Sing and Agrwal, 2007). Physico-chemical analysis of waste water (Table 2) indicated that the EC value may cause increase in the soil salinity which may cause reduction of plant growth (Iqbal et al., 2013). 
A reduction in chlorophyll contents was recorded in tomato, okra and pumpkin. Chlorophyll $b$ exhibited more decline than chlorophyll $a$. Similar, reductions in chlorophyll contents were exhibited by Beta vulgaris subjected to sewage water irrigation (Sing and Agrawal, 2010). According to Marwari and Khan (2012) irrigation of tomato plants with 20 and $30 \%$ sewage water badly affected the chlorophyll contents, indicating that the decrease may be due to reduction of chlorophyll biosynthesis under stress (Bamniya et al., 2010).

Carotenoid contents increased in all vegetables due to sewage water irrigation and this increase was more pronounced at $100 \%$ level of domestic sewage water irrigation. Increase of carotenoid contents is considered, a defense role in plants to alleviate metal stress (Sinha et al., 2007).

The antioxidants like SOD, APX, CAT and POD also showed an increment in activity (Fig. 2), responsible for scavenging of reactive oxygen species (ROS) (Table 4) (Noctor and Foyer, 1998). They play a defensive role against oxidative stress and indicators of metal uptake (Radotic et al., 2000). Similar results are observed in palak (Beta vulgaris var All Green) irrigated with different concentrations of sewage water (Singh and Agrawal, 2007). According to Ashraf (2009) antioxidants detoxify $\mathrm{H}_{2} \mathrm{O}_{2}$ (ROS) into $\mathrm{H}_{2} \mathrm{O}$ (water) into $\mathrm{O}_{2}$ (Sairam et al., 2005) and relieve the oxidative damage in plants caused by ROS. Total phenolics and flavonoids behave like antioxidants and also act in $\mathrm{H}_{2} \mathrm{O}_{2}$ - scavenging system. Under multiple stresses, phenolic metabolism induction is observed in plants (Michalak, 2006). Flavonoids play an important role in plant-environment interactions under low concentrations (Fini et al., 2011). An increase in phenolic compounds was observed in Albizia lebbek under heavy metal stress (Tripathi and Tripathi, 1999). In the present work irrigation with waste-water increased phenolic contents and flavonoids with maximum values recorded at $100 \%$ concentration of sewage water (Fig. 2). Similarly, nickel and aluminum contents resulted increase in phenolic contents in wheat (Diáz et al., 2001) and maize (WinkelShirley, 2002). In biological systems, the presence of malondialdehyde as oxidation products is directly related to the peroxidation of unsaturated fatty acids constituting cellular membranes (Turton et al., 1997). Plants irrigated with waste-water exhibited higher MDA concentration, as compared to those irrigated with fresh water. Heavy metals cause peroxidation of lipid membranes due to the formation of ROS and free radicals, leading to enhanced permeability and oxidative stress to the plants (Nada et al., 2007; Zhang et al., 2007). 
Table 3. Mean squares values from analysis of variance (ANOVA) of data for morpho-physiological attributes of tomato, okra and pumpkin treated with sewage water

\begin{tabular}{|c|c|c|c|c|c|c|c|c|c|}
\hline SOV & df & $\begin{array}{c}\text { Shoot } \\
\text { fresh } \\
\text { weight }\end{array}$ & $\begin{array}{c}\text { Root } \\
\text { fresh } \\
\text { weight }\end{array}$ & $\begin{array}{c}\text { Shoot } \\
\text { dry weight }\end{array}$ & Root dry weight & Fruit fresh weight & $\begin{array}{c}\text { Fruit } \\
\text { dry weight }\end{array}$ & Chla & Chlb \\
\hline Variety (V) & 2 & $571588.54 * * * *$ & $1160.066^{* * *}$ & $6207.34 * * *$ & $711.846^{* * *}$ & $10425.6 * * *$ & $36.933 * * *$ & $0.342 *$ & $0.512 * *$ \\
\hline Treatment $(\mathrm{T})$ & 2 & $196299.68 * * *$ & $1087.189 * * *$ & $1869.59 * * *$ & $315.384 * * *$ & $573.6^{* *}$ & $11.044 * *$ & $0.564 * *$ & $0.238 *$ \\
\hline Interaction (VxT) & 4 & $54865.411 *$ & $345.412 * *$ & $277.57 *$ & $24.379 \mathrm{~ns}$ & $189.3 \mathrm{~ns}$ & $2.199 * *$ & $0.0139 \mathrm{~ns}$ & $0.048 \mathrm{~ns}$ \\
\hline Error & 36 & 15577.445 & 75.983 & 110.71 & 12.515 & 163.2 & 0.595 & 0.086 & 0.0622 \\
\hline Total & 44 & & & & & & & & \\
\hline
\end{tabular}


Table 4. Mean squares values from analysis of variance (ANOVA) of data for antioxidants of tomato, okra and pumpkin treated with waste water.

\begin{tabular}{|c|c|c|c|c|c|c|c|c|c|}
\hline SOV & df & $\begin{array}{l}\text { Carotenoid } \\
\text { contents }\end{array}$ & APX & SOD & POD & CAT & MDA & Flavanoids & Phenolics \\
\hline $\begin{array}{l}\text { Variety } \\
\text { (V) }\end{array}$ & 2 & $0.781 * * *$ & $3.701 * * *$ & $3.701 * * *$ & $1354.182 * *$ & $3228.694 * * *$ & $160.267 * * *$ & $185.258 *$ & $\begin{array}{l}14129.317 * * \\
*\end{array}$ \\
\hline $\begin{array}{l}\text { Treatment } \\
\text { (T) }\end{array}$ & 2 & $0.177 \mathrm{~ns}$ & $2.119 * * *$ & $2.119 * * *$ & $4466.678 * * *$ & $5272.703 * * *$ & $502.708 * * *$ & $559.065 * * *$ & $\begin{array}{l}23921.799 * * \\
*\end{array}$ \\
\hline VxT & 4 & $0.017 \mathrm{~ns}$ & $0.133 n s$ & $0.239 \mathrm{~ns}$ & $48.058 \mathrm{~ns}$ & $122.394 \mathrm{~ns}$ & $30.536^{*}$ & 4.584 & $1871.005 \mathrm{~ns}$ \\
\hline Error & 36 & 0.071 & 0.174 & 0.879 & 160.809 & 75.297 & 7.800 & 49.047 & 1061.001 \\
\hline Total & 44 & & & & & & & & \\
\hline
\end{tabular}




\section{Conclusion}

Irrigation with waste-water is a common technique for cultivation of crops including vegetables in third world countries. It enhanced the biomass of tomato, okra and pumpkin on $50 \%$ dilution. However, its use as a nutrient source depends on the type of a crop grown, fertility level of soil and nutrients concentration. Waste water should be diluted with fresh water in areas having shortage of irrigation water. But still it should be checked for its heavy metal contents to avoid risk on human and animal lives.

\section{REFERENCES}

[1] Arnon, D I. (1949): Copper enzyme in isolated chloroplasts polyphenol oxidase in Beta vulgaris. - Plant Physiolgy 24: 1-15.

[2] Ashraf, M. (2009): Biotechnological approach of improving plant salt tolerance using antioxidants as markers. - Biotechnology advances 27(1): 84-93.

[3] Bakhsh, A., Kanwar, R.S., Karlen, D.L. (2005): Effects of liquid swine manure applications on NO 3-N leaching losses to subsurface drainage water from loamy soils in Iowa. - Agriculture, Ecosystems \& Environment 109(1):118-128.

[4] Bamniya, B. R., Kapasya, V., Kapoor, C. S. (2010): Physiological and biochemical studies on the effect of waste water on selected crop plants.- Biological Forum International Journal 2 (2): 1-3.

[5] Cakmak, I. (1994): Activity of ascorbate-dependent $\mathrm{H}_{2} \mathrm{O}_{2}$-scavenging enzymes and leaf chlorosis are enhanced in magnesium-and potassium-deficient leaves, but not in phosphorus-deficient leaves.- Journal of Experimental Botany 45(9): 1259-1266.

[6] Camak, I., Horst, W. J. (1991): Effect of aluminium on lipid peroxidation, superoxide dismutase, catalase and peroxidase activities in root tips of soyabean (Glycine max).Physiologia Plantarum 83(3): 463-468.

[7] CCME. (2007): Canadian soil quality guidelines for the protection of environmental and human health. Canadian Council of Ministers of the Environment, distribution in plants of lactuca sp. Ca-Mn interaction.- Journal of Plant Science 162: 761-767.

[8] Chance, B., Maehly, A. C. (1955): Assay of catalase and peroxidase.- Methods in Enzymology 2: 764-775.

[9] Diaz, J., Bernal, A., Pomar, F., Merino, F. (2001): Induction of shikimate dehydrogenase and peroxidase in pepper (Capsicum annum L.) seedlings in response to copper stress and its relation to lignification. -Plant Science 161: 179.

[10] Environment Protection Authority.(1991): 'Guidelines for wastewater irrigation', Publication 168, Environment Protection Authority, Melbourne.

[11] FAO.(2002): Sewage flow in major cities of Pakistan. Food and Agricultural Organization, Islamabad, Pakistan.

[12] Farooq, M., Anwar, F., Rashid, U. (2008): Appraisal of heavy metal contents in different vegetables grown in the vicinity of an industrial area. - Pakistan Journal of Botany 40(5): 2099-2106.

[13] Fini, A., Brunetti, C., Di Ferdinando, M., Ferrini, F., Tattini, M. (2011): Stress-induced flavonoid biosynthesis and the antioxidant machinery of plants. - Plant Signaling \& Behavior 6(5): 709-711.

[14] Giannopolitis, C. N., Ries, S. K. (1977): Superoxide dismutases occurrence in higher plants. - Plant Physiology 59: 309-314.

[15] Hassan, F. A., Ali, H. M. (2013): Impact of irrigation with Sewage effluent on the growth and wood properties of two forest tree seedlings. - Journal for Forest Products \&Industries 2: 40-44. 
[16] Ilaco, B. V. (1985): Agricultural compendium, for rural development in the tropics and subtropics, international land development consultants LTD., Netherlands; commissioned by the ministry of agriculture and fisheries. - The Netherlands Elsevier Scientific Publishing, The Hague.

[17] Iqbal, F., Ali, S., Tauqeer, H. M., Shakoor, M. B., Farid, M., Iftikhar, U., Nazir, M. M. (2013): Assessment of ground water contamination by various pollutants from sewage water in Chakera village, Faisalabad. - International Journal of Environmental Monitoring and Analysis 5: 182-187.

[18] Kakar, S. R., Wahid, A., Tareen, R. B., Kakar, S. A., Tariq, M., Kayani, S. A. (2010): Impact of municipal waste water of Quetta city on biomass, physiology and yield of canola (Brassica napus L.). - Pakistan Journal of Botany 42(1): 317-328.

[19] Marwari, R., Khan, T. I. (2012): Effect of textile waste water on tomato plant, Lycopersicon esculentum. - Journal of Environmental Biology 33(5): 849.

[20] Khan, A., Javid, S., Muhmood, A., Mjeed, T., Niaz, A., Majeed, A. (2013): Heavy metal status of soil and vegetables grown on peri-urban area of Lahore district. - Soil and Environment 32(1): 49-54.

[21] Khan, M.A., Shaukat, S.S., Khan, M.A. (2008). Economic benefits from irrigation of maize with treated effluents waste stabilization ponds. - Pakistan Journal of Botany 40:1091-1098.

[22] Kirk, J. T. O., Allen, R. L. (1965): Dependence of chloroplast pigment synthesis on protein synthesis: effect of actidione. - Biochemical and Biophysical Research Communications 21(6): 523-530.

[23] Kouser, S., Samie, A. (2009): Wastewater use in cauliflower production and farmer's health: an economic analysis. - The Pakistan Development Review 47-66.

[24] Kumar, V., Chopra, A. K., Pathak, C., Pathak, S. (2010): Agro-potentiality of paper mill effluent on the characteristics of Trigonella foenum-graecum L.(Fenugreek). - New York Science Journal 3(5): 68-77.

[25] MAAF. (1988): Fertilizer Recommendation. Reference Book 209. - HMSO, London

[26] Magen, H. (2005). Potential development of fertigation and its effect on fertilizer use.Fertigation Proceedings: Selected papers presented at the joint 20:49.

[27] Marwari, R., Khan, T. I. (2012). Effect of textile waste water on tomato plant, Lycopersicon esculentum. - Journal of Environmental Biology 33(5): 849.

[28] Michalak, A. (2006): Phenolic compounds and their antioxidant activity in plants growing under heavy metal stress. - Polish Journal of Environmental Studies 15 (4): 523-530.

[29] Musa, J. J., Dauda, S. M., Abubakar, S. M., Fumen, G. (2013): Evaluation of Wastewater from a Refinery Treatment Plant for Agricultural Use.- International Journal of Science, Engineering and Technology Research (IJSETR) 2(1): 69-73.

[30] Nada, E., Ben, A.F., Rhouma, A., Ben, R.B., Mezghani, I., Boukhris, M.(2007): Cadmium-induced growth inhibition and alteration of biochemical parameters in almond seedlings grown in solution culture. - Acta Physiologiae Plantarum 29: 57-62.

[31] Noctor, G., Foyer, C. H. (1998): Ascorbate and glutathione: keeping active oxygen under control. - Annual review of plant biology 49(1): 249-279.

[32] Noctor, G., Foyer, C. H. (1998): Ascorbate and glutathione: keeping active oxygen under control. - Annual review of plant biology 49(1): 249-279.

[33] Park, Y. S., Jung, S. T., Kang, S. G., Heo, B. G., Arancibia-Avila, P., Toledo, F., Gorinstein, S. (2008): Antioxidants and proteins in ethylene-treated kiwifruits. - Food Chemistry 107(2): 640-648.

[34] Radotic, K., Ducic, T., Mutavdzic D. (2000): Changes in peroxidase activity and isozymes in spruce needles after exposure to different concentrations of cadmium. Environmental and Experimental Botany 44: 105-113.

[35] Rattan, R. K., Datta, S. P., Chhonkar, P. K., Suribabu, K., Singh, A. K. (2005). Long-term impact of irrigation with sewage effluents on heavy metal content in soils, crops and groundwater-a case study. - Agriculture, Ecosystems \& Environment 109(3): 310-322. 
[36] Saeed, R., Ahmad, R. (2009): Vegetative growth and yield of tomato as affected by the application of organic mulch and gypsum under saline rhizosphere. - Pakistan Journal of Botany 41(6): 3093-3105.

[37] Sairam, R. K., Srivastava, G. C., Agarwal, S., Meena, R. C. (2005): Differences in antioxidant activity in response to salinity stress in tolerant and susceptible wheat genotypes. - Biologia Plantarum 49(1): 85-91.

[38] Singh, A., Agrwal, M. (2007): Effects of sewage sludge amendment on heavy metal accumulation and consequent responses of Beta vulgaris plants. - Chemosphere 69: 22292240.

[39] Singh, A., Agrwal, M. (2010): Effect of municipal waste water irrigation on availability heavy metals and morpho-physiological characteristics of Beta vulgaris L. - Journal of Environmental Biology 31(5): 727-736.

[40] Sinha, S., Gupta, A. K., Bhatt, K. (2007): Uptake and translocation of metals in fenugreek grown on soil amended with tannery sludge: involvement of antioxidants. Ecotoxicology and Environmental Safety 67(2): 267-277.

[41] Tripathi, A.K., Tripathi, S. (1999): Changes in some physiological and biochemical characters in Albizia lebbek as bioindicators of heavy metal toxicity. - Journal of Environmental Biology 20: 93-98.

[42] Turton, H.E., Dawes, I.W., Grant, C.M. (1997): Saccharomyces cerevisiae exhibits a yAP-1- mediated adaptive response to malondialdehyde. - Journal of Bacteriology 179: 1096-1101.

[43] United States Salinity Laboratory Staff (USSL). (1954): Diagnosis and improvement of saline and alkali soils, Agriculture Handbook No. 60, U.S. Department of Agriculture, Washington, D.C.

[44] Ullah, R., Malik, R. N., Qadir, A. (2009): Assessment of groundwater contamination in an industrial city, Sialkot, Pakistan. - African Journal of Environmental Science and Technology 3(12).

[45] WHO. (2007): Joint FAO/WHO Expert standards program codex Alimentarius Commission. Geneva, Switzerland. - Available online http://www.who.int.

[46] Winkel-Shirley, B. (2002): Biosynthesis of flavonoids and effects of stress. - Current Opinion in Plant Biology 5: 218-223.

[47] Wolfe, K., Wu, X., Liu, RH. (2003): Antioxidant activity of apple peels. - Journal of Agricultural and Food Chemistry 51:609-614.

[48] Zhang, F.Q., Wang, Y.S., Lou, Z.P. Dong, J.D. (2007): Effect of heavy metal stress on antioxidative enzyme and lipid perdoxidation in leaves and root of two mangrove plant seedlings (Kandelia candel and Bruguiera gymnorrhiza). - Chemosphere 61:44-50. 